\title{
Enforcement of Human Rights: Effectiveness of International Legislation
}

\author{
Devarshi Mukhopadhyay*
}

\begin{abstract}
The juxtaposition of legal sovereignty against international duty (in the form of fostering greater respect for human rights across the globe) became one of the founding attributes of the post World War II political regime. Several human rights legislations were coined, deliberated upon, and ratified. However, the fact that ratification alone has not led to better human rights regime is something that many would not deny. In fact, this entire concept of drafting soft law principles has been cynically questioned by critics, citing the lack of a proper enforcement mechanism and real legitimacy as reasons for its failure. Moreover, several empirical studies have been evidence of the fact that respect for human rights is more intrinsically connected with ancillary principles such as a democratic regime, the strength of participation of civil society, the conflict status of a country and several others, and not treaty ratification alone. It is this claim that the researcher has analyzed in the course of this paper.
\end{abstract}

Keywords: Governance, Human Rights, International Community Legislation, Treaty.

\section{Introduction}

Amidst long lasting argumentative discourse, critics of international human rights treaties argue against the real

* BA LLB (Hons), NALSAR University of Law, Hyderabad, India; mukherjee.devarshi@gmail.com. 
effectiveness of soft law legislation, citing examples of nations that have ratified treaties but failed to implement them within domestic territory, which only weakens the very basis of human rights legislation. While the gap between universal right and remedy becomes even more unavoidable, the question which automatically puts the validity of documents such as the Universal Declaration of Human Rights 1948 (UDHR) or the International Covenant on Civil and Political Rights 1966 (ICCPR) at stake, is whether such treaties substantially improve respect for human right standards or not. Other relevant human rights treaties displaying the same problems include the International Convention on the Elimination of all forms of Racial Discrimination 1966 (ICERD), Convention on the Elimination of All Forms of Discrimination against Women 1979 (CEDAW), Convention against Torture and Other Cruel, Inhuman or Degrading Treatment or Punishment 1984 (CATOCIDTP.) and Convention on the Rights of the Child 1989 (CRC). If a statistical analysis into the compliance records of nations which have signed as well as ratified such documents is undertaken, the fact that such a proposition is not unfounded is significantly proved. A classic example of such non compliance is the Equatorial Guinea, which ratified the ICCPR 1966 on the $25^{\text {th }}$ day of September, 1987. A Human Rights Watch report on the occurrence of human rights violations in the area has documented the extent up to which corruption, poverty, and repression continue to plague the country under President Teodoro Obiang Nguema Mbasogo, who has been in power since $1979.1^{1}$ A country is heavily driven to preserve its reputation in the international arena; ${ }^{2}$ ratification is only a preliminary move to preserve the same and in no way ensures better compliance. ${ }^{3}$

The major compliance mechanisms that exist in other areas of international law are mostly absent in the area of human rights.

\footnotetext{
${ }^{1}$ Human Rights Watch, Equatorial Guinea: Human Rights Concerns Ahead of Elections (May 7, 2013), available at http:/ /www.hrw.org/news/2013/ 05/ 07/equatorial-guinea-human-rights-concerns-ahead-elections.

2 Andrew T. Guzman, A Compliance-Based Theory of International Law, 90 CAL. L. REV. 1823 (2002).

3 See Louis Henkin, How NATIONS BeHAve (Columbia University Press $2^{\text {nd }}$ ed. 1979).
} 
Unlike finance or trade, there is a lack of economically determined forces of the globalized market that more often than not, force compliance by means of systemic interaction. Structurally different from agreements in trade, non compliance does not have a prescribed punishment mechanism, stemming from the fact that a nation's actions against its own citizens do not directly threaten or harm other states. ${ }^{4}$ For instance, if one were to talk specifically about global trade, the General Agreement on Tariffs and Trade, through its dual principles of 'most favored nation treatment' as well as 'national treatment', ensure that by and large, arbitrary and unfair discrimination of imported products in the domestic markets is reduced. This was specifically observed in the Japan-Taxes on Alcoholic Beverages Case, ${ }^{5}$ wherein the concerned World Trade Organization (WTO) Panel unanimously ordered the immediate withdrawal of a locally produced brand of Japanese alcohol, which was being awarded arbitrary benefits under a local tax law. The result of this was the withdrawal of the tax benefit by the Japanese government. The purpose of providing this example is only to prove that the scope that exists for non compliance to universally accepted principles of compliance is much lesser when compared to the field of human rights. As far as trade and finance are concerned, market forces coupled with national commercial interest are the primary reason for observing better records of compliance. Therefore, it is contended that international human rights treaties do not substantially increase the overall respect for internationally accepted principles of human rights.

\section{Cultural Relativism and Critical Legal Jurisprudence}

The issue of cultural relativism, which envisages the role of the state in fostering respect for cultural norms and traditions, further puts the universality of human rights at jeopardy. Owing to such cultural norms and traditions that are given predominance over the rule of international law, respecting the terms put down in a ratified treaty becomes a matter of discretion rather than a matter

4 Stephen D. Krasner, SOVEREIGNTY: ORgANIZED HYPOCRISY 364-365 (Princeton University Press 1999).

5 Appellate Body Report, Japan-Taxes on Alcoholic Beverages, WT/DS8/AB/R, WT/DSI0/AB/R, WT/DSI1I/AB/R (Oct. 4, 1996). 
of obligation. Questions of this nature have become inherently important to human rights discourse, gauging from the expenditure of both time and money involved in the drafting and deliberation of any international legislation and the continual denial of rights inalienable to every human being.

Several schools of political theory have employed methods of empirical as well as analytical study into this field of research, only to be further exasperated at not being able to answer its daunting questions in terms of a simple yes or no. ${ }^{6}$ Indeed, the past has been witness to the growing need of countries across the globe to improve upon their image, leading them to ratify conventions and treaties and eventually abandon the same within domestic territory. While it can be said that the lack of enforcement of international bodies and the utmost authority of sovereignty becomes the essential cause of this, it can be seen that democracies and autocracies respond differently to various situations in international human rights law. The critical political interplay between public opinion and law in democracies has a crucial role to play in the effectiveness of international legislation in countries. It is a widely held view that democracies tend to give more respect to international legislation in general.

A classical realist argument, heavily influenced by the assumption that states are unitary actors entering the political power play primarily to serve their own geopolitical interests, contends that the citizens of one country are not substantially affected by human rights violations in other countries, which is precisely why it would make very little sense (from a strictly utilitarian viewpoint) for a country like the United States to put their oil trade relations with Saudi Arabia in any sort of jeopardy because the latter has displayed an atrocious human rights record since time immemorial. Interestingly, while on one hand, the United States has ratified only seven International Labour Organization (ILO) human rights treaties out of nineteen, the same country has a Foreign Assistance Act 1961 that promises not to provide any sort of financial aid to countries engaging in a consistent pattern of

6 Douglass Cassel, Does International Human Rights Law Make a Difference?,

2 CHI. J. INT'L L. 121, 121-135 (2001). 
gross violation of internationally recognized human rights. ${ }^{7}$ It is therefore extremely difficult to trace the behavior of a country in the past and predict its future actions based on such findings. Similarly, unless and until there is a significant percentage of Indians living in a country such as North Korea or Equatorial Guinea who are subject to gross violations, there is no reason to suspend a bilateral agreement between the two countries. The battle here is about what is more profitable to do instead of what should be done, reinforcing the propositions of legal realism. However, the one inference which can be made from a realist argument is about the ability of the first world to influence respect for human rights, in the event of such a country going ahead and enforcing legislation dealing with non compliance (as in the case of USA).

A second proposition, put forward by the desegregationist, attacks the state centric definition put forward by the functionalists and realists, by saying that states are not monolithic units. This particular group of theorists, consisting of Non-Governmental Organizations (NGOs), Transnational Corporations (TNCs), professional associations and other social classes, emphasize the fact that the State comprises of a group of persons with varying interests. An argument flowing directly from such a proposition is the role of NGOs as 'institutionalist enablers' or as activists capable of change, setting in motion the process for domestic policy change. In fact, history has long been witness to NGOs often conducting independent research that potentially influences state policy. By playing a role greater than simply assisting states in the pursuance of their agenda, these independent entities are more devoted to a specific agenda, to which the particular regime may not have devoted enough attention. Instances of such behavior have been exhibited through the role of NGOs playing a significant role in the United Nations designation of the Decade for Women's Rights and the establishment of the International Criminal Court. ${ }^{8}$ While there is general consensus on the fact that a country comprises various

7 The Foreign Assistance Act, 22 U.S.C. § 116.

8 United Nations, Global Issues: Women, available at http://www.un.org/en/globalissues/women/ (last visited Dec. 16, 2013). 
pressure groups and other relevant domestic actors, this theory primarily posits that democracies are more likely to comply with supranational legal judgments, considering the fact that international legal obligations mobilize domestic interest groups to exert pressure on the government to comply with accepted standards. ${ }^{9}$ In fact, it would be more useful to look at the sort of interaction and internalization processes laid down by the proponents of the transnational human rights advocacy school. Several scholars from this school of thought suggest that certain transnational actors such as diplomats or NGOs form what they call an 'epistemic human rights community', who play an exceedingly important role in the entire negotiation model.

The final treaty text (drafted after the conclusion of the deliberation processes) represents the common interpretation of both the state actors as well as the other players within domestic law, so as to uphold the spirit of any international legislation as far as possible. Human rights networks consisting of dedicated parties enable a rather long (or maybe even short) period of transition from unconstrained repression to rule consistent behavior via modes of denial, tactical concessions and prescriptive status. Initially, of course, the domestic political opposition is too weak to constrain human rights violations and the country manages to escape the attention of transnational advocacy networks. However, triggered by events of particularly gross human rights violations, the network automatically starts putting the regime under pressure by disseminating information, putting in jeopardy the public image of the same, and mobilizing international public opinion against it. While offending countries usually respond in the mode of denial, there is a probable change in this attitude, where sustained pressure and criticism leads to a desire to diffuse such international image. If one takes the example of the Republic of India, the transition from absolute non compliance to gradual respect becomes clear.

Human right violation in the form of caste atrocities have been one of the initial roots of what many perceive as an excessively

9 Martti Koskenniemi, The Place of Law in Collective Security, 17 MicH. J. INT'L L. 455 (1996). 
repressive social structure. In 2007, the United Nations Committee on Elimination of Racial Discrimination, reported acts of the state engaging in extrajudicial killings and arbitrary arrest against the members of the so called backward castes, the scheduled castes and tribes, occupying the lowest position in the Varna system of India. ${ }^{10}$ Human rights violations ranged from arbitrary acts such as killing, rape, humiliation, among other forms of the worst kinds of human rights violations. Initially, there was very little that the government could do, following from the fact that caste division had a lot to do with the electoral politics in the country, and the huge percentage of the vote bank that the upper castes commanded. However, the landmark move towards compliance came with India's ratification of the International Convention on the Elimination of all forms of Racial Discrimination (ICERD) in 1968, which was shortly followed by the passing of the Scheduled Castes and Tribes (Prevention of Atrocities) Act 1989, which when read with Article 17 of the Indian Constitution, bans every form of discrimination throughout the country. Even though such legislation hasn't been able to combat issues surrounding discrimination against other groups such as the religious minorities very effectively, caste based discrimination has reduced to a significant extent, a major reason for exerting pressure by the international community, as well as sustained efforts on part of the media to expose the backwardness of traditional social perception. The period ranging from the adoption of the ICERD Convention in 1968 until the passing of the domestic legislation in 1989, was marked by several international research organizations and NGOs which engaged in a detailed deliberation process with most of the instruments of the state and managed to cause a change in thinking. This of course was backed by the media conducting trials on a daily basis, enabling scholars and activists to influence public thinking towards a more positive direction. This again shows clearly the sort of effect that public opinion has on the enactment of the law.

10 U.N. Comm. on the Elimination of Racial Discrimination, Consideration of Reports Submitted by States Parties under Art. 9 of the Convention, 14 U.N. Doc. CERD/C/IND/CO/19 (May 5, 2007). 


\section{Procedural Changes in International Governance}

The value that the vote bank has to the ruling party or coalition in any democracy is probably the one thing which may lead to an upward sloping graph of human rights records. In this regard, the principal recommendations put forward by Professor Bayefsky in The UN Human Rights Treaty System: Universality at the Crossroads, ${ }^{11}$ talks at length about a reporting process, whereby state parties will mandatorily be required to submit to the international arena, a report of their progress/compliance with the terms and conditions set out in the treaties which they have ratified. The primary issue with such a proposition is the absence of a monitoring system which ensures that such reports have information which is valid in its entirety and the action which it claims to have taken has actually been taken. What appears relatively more practical, although expensive, is establishing a monitoring department of the United Nations (within the ambit of the Office of the United Nations High Commissioner of Human Rights) in countries which display particularly poor records and propose a model like the United States did, through its Foreign Assistance Act 1961 hoping to cause better standards of compliance. Similarly, logistical impediments such as information sharing by means of a central database system have prevented an increase in the efficiency of the bodies established by the treaties themselves, creating further lacunae in the enforcement machinery. As regards the issue of monitoring, problems of staff members being continuously shifted and therefore losing track of conditions prevailing in a certain country, the researcher contends the establishment of a permanent area specific staff body, whose shift in that area lasts for as long as that particular phase of reporting has not been completed. What therefore becomes evident is that the literature of these treaties set the heights of utopia as their objective, while it doesn't necessarily have the means or the established system to accomplish it.

\footnotetext{
${ }^{11}$ Anne F. Bayefsky, The UN Human Rights Treaty System: Universality at the Crossroads (Apr. 2001), available at http://www.bayefsky.com/report/ finalreport.pdf.
} 
Institutionalism takes a slightly more optimistic view of the international political arena, proposing that political actors will comply with international standards as a result of strategy. In contrast with realist theoretical models, the institutionalists seek to study the reasons behind the existence of international institutions, but weigh the costs against the benefits to decide whether or not rules are to be complied. ${ }^{12}$ Here too, countries face a dilemma similar to the one put forward by the neo realist school of thought that whether a threatening group would go ahead with a sanction even after knowing that the costs of such an action would easily overshadow the benefits? ${ }^{13}$ A major institutionalist assumption is also that cooperation forms the basis of international law. In situations where such cooperation is clearly at stake, will global actors make the compromise? Evidently, reflections from the $21^{\text {st }}$ century prove beyond reasonable doubt that the chances are relatively bleak. While the number of treaty ratifications has increased from a meager 243 in 1980 to an astounding 926 in 2000,14 there is lesser doubt about the fact that more and more countries of the world, have resorted to the strategy which this school talks about. A strategy not made with the sole objective of granting citizens their inalienable rights, but to improve an individual nation's image globally. Syria was one of the original 48 countries that voted in favour of Universal Declaration of Human Rights on December 10, 1948 (UDHR). Soon after the outbreak of the Arab Spring, Syrian government forces, in collaboration with the deadly Shabiha went on a systematic rampage to counter the rebels. The Shabiha are an allegedly state sponsored group of armed men and terrorists who committed what Amnesty International reports as one of the bloodiest armed conflicts in the history of mankind. These atrocities have been committed in areas extending from Idlib to Jebel-Al-Zawiyah, reinforcing the volatile nature of human rights in the face of conflict. ${ }^{15}$ What one can clearly gauge from the

12 The EXPANSION Of INTERNATIONAL SOcIETY (Hedley Bull et al. eds., Oxford University Press 1984).

13 The POWER of Human Rights: InTERnational Norms And DOMESTiC CHANGE (Thomas Risse et al. eds., Cambridge University Press 1999).

14 Supra note 11.

15 Amnesty International, Deadly Reprisals: Deliberate Killings and Other Abuses by Syria's Armed Forces (Jun. 14, 2012), available at 
behavior of the afore mentioned country is how weak the human rights regime actually is. The country which at the time of ratification seemed to be committed to the ideals of the UDHR ruthlessly went about violating most of its terms when threatened in domestic territory. While we do somewhere agree that ratification of treaty does form the basis of a start to fostering greater respect in the future, what plagues the minds of critics is when such a time in the future shall actually come. It is practically impossible to predict future behavior, considering the fact that non compliance can happen any number of years after the treaty has been adopted. Syria acted nearly 60 years after it ratified the UDHR in 1948. Hence, the best that international political actors can do is to start enforcing treaty provisions from the very beginning itself, so that the change is not temporary but systemic.

What transpires from the examination of the propositions put forward by the various jurisprudential schools of thought in matters of human rights is that the patterns of democracy and the role of civil society have a direct impact on human rights compliance. Drafting more treaties does not essentially make any relevant difference to what countries promise to do at an international platform but completely ignore to do within domestic territory. Moreover, owing to the lack of force, enforcement becomes a gradual impossibility as well, exposing the lacunae in the international legal principles with each passing day. As the world's most repressive societies torture human beings every day, international political players face two pivotal questions. First, whether democracy is the only answer to better human rights records (thereby signaling the absolute dearth of efficiency of the international bodies to enforce compliance in non democracies) and second, whether further treaty formulation will do any real good to respect for human rights or not. The researcher believes that the $21^{\text {st }}$ century is one where growth commands policy-making in general and foreign policy in particular, resulting in a diminishing importance of respect for human beings and the rights guaranteed to them by birth. In a time like this, we cannot ask for better human rights standards. There is no greater force in this world than the 
will of the people, as was clearly evidenced when the Arab Spring broke out. The basic fact of the matter still remains that revolution rests upon the mass, and not the governing minority. With the economic meltdown of 2007 disrupting established commercial order and the throne of the economic hegemon now up for grabs, we cannot reasonably expect a miraculous effort of states to enforce treaty provisions. Therefore, it wouldn't be unreasonable to contend that revolution is the only way to better enforcement. The formulation of more treaties does not substantially increase the global respect for human rights.

\section{Effectiveness of the Institutionalized Law Making Processes}

In the last part of this paper, focus is laid on the institutionalized law making process (specifically the enforcing capacity of the Security Council) and whether or not international human rights treaties, while empowering such bodies, actually make their tasks easier/possible. In fact, the question of enforcement after formulation becomes most important to any human rights debate.

One would often be driven to believe, that the ambiguity in the language of several legislations of international law reflects upon the intent of the peace loving community to accommodate the changing face of the law per se, and aim at greater fulfillment of purpose. Such ambiguity is clearly evident in the wording of Article 2(4), 2(7) and 51 of the Charter of the United Nations, which use rather non self-explanatory terms such as 'use of force' or 'territorial integrity' or even 'political independence'. The past has seen immense criticism surrounding the 'real' powers vested in the Security Council, when nations of the world blatantly went around disobeying treaty provisions, the Rwandan Genocide being the best example of international inaction in the face of the 'responsibility to protect'. While the authority of enforcement, spoken about in Chapter VII has hardly ever been resorted to, the Security Council did not do too much to interpret the Charter's apparent triggers for such action (Article 39), the preconditions and scope of the Council's authorized responses (under Articles 40-42) or even the meaning of 'enforcement action' for the purposes of Article 2(7). Juxtaposing the intervention following the Korean Peninsular 
Crisis or the actions of the Council in Kuwait, against its peacekeeping missions in Congo or Suez, the researcher notes two things. Firstly, peacekeeping missions have often been extremely long and ineffective and secondly, the Security Council, by way of the political structure in the permanent seats, rarely has the chance of resorting to armed intervention, in its pursuit to enforce human rights treaties. However, the Security Council itself has devised innovative means to do more than what the law allows it to, for the sake of human rights protection. For example, the forms of peacekeeping discussed by the International Court of Justice (ICJ) provide a restricted scope of the authority of the UN Despite the power of territorial administration not being granted under the International Trusteeship System under Article 78 of the Charter, Resolution 678 of $1990^{16}$ was a clear instance of innovation in the face of conflict. If the treaties themselves legitimize such practices, it automatically allows for a greater amount of potential work for the upliftment of human rights standards.

In light of the Security Council's ambiguous deployment of its declarative and interpretative functions, enforcement needs greater legitimacy. By virtue of rights guaranteed to an individual by birth, it becomes by default, the obligation of the international community to ensure that such rights are not taken away. Caught in the battle between cultural relativism and international obligation, examples from world politics show that more treaties are not of substantial use, unless the entire system is restructured in a manner conducive to enforcement and greater respect for human rights.

\section{Conclusion}

Examples from world politics often do confirm with theories put forward by various schools of jurisprudence, displaying behavior that conforms to predictions made by such thinkers. While it is true that political patterns are changing and a greater number of countries are displaying better human rights records, this positive shift is only minimal and not substantial. The reason behind this is that even the highest deliberation platforms in the world, such as

16 S.C. Res. 678, U.N. Doc. S/RES/678 (Nov. 29, 1990). 
the United Nations, have members who have a very limited idea as to what human rights are and why they are so important to us. Countries in the continent of Africa are the best example of this. For several such countries, torture and absolute obedience has been the way of life since inception and any effort to change this would amount to a direct attack on an individual countries' sovereignty. Similarly, there are numerous countries in the Middle East, where even after revolution has struck, the masses themselves prefer autocratic governance, which in turn paves way for the blatant discretion of obeying international law principles. What we can therefore gauge, is that ratification of treaty is only the beginning of fostering greater respect for human rights. There is a need for restructuring world politics in a manner conducive to enforcement of human rights. 